\title{
A CLINICAL STUDY OF MORBIDITY AND MORTALITY PATTERN OF LATE PRETERM INFANTS AT SNCU, WARANGAL
}

Sudhakar Ajmera ${ }^{1}$, Surender K², Boppidi Santosh Avinash 3 , Banoth Balram 4

${ }^{1}$ Assistant Professor, Department of Paediatrics, MGM Hospital, Kakatiya Medical College, Warangal, Telangana State, India. ${ }^{2}$ Assistant Professor, Department of Paediatrics, MGM Hospital, Kakatiya Medical College, Warangal, Telangana State, India. ${ }^{3}$ Post Graduation, Department of Paediatrics, MGM Hospital, Kakatiya Medical College, Warangal, Telangana State, India. ${ }^{4}$ HOD and Professor, Department of Paediatrics, MGM Hospital, Kakatiya Medical College, Warangal, Telangana State, India.

\section{ABSTRACT}

\section{OBJECTIVE}

A clinical study of morbidity and mortality pattern of late preterm infants in comparison with term infants.

\section{STUDY DESIGN}

Prospective observational study.

\section{SETTING}

SNCU, Mahatma Gandhi Memorial Hospital, Warangal.

\section{SUBJECTS}

Consecutive sample of late preterm infants and term infants referred to our hospital on or before fourth day of life.

\section{RESULTS}

76 late preterm infants and 76 term infants with any of the pre-defined neonatal condition were included in the study. Late preterm infants were significantly at a higher risk for overall morbidity including hypothermia, sepsis, respiratory morbidity, jaundice, hypoglycemia, birth asphyxia. A trend towards higher mortality was also seen.

\section{CONCLUSION}

In an out born referral center, late preterm infants are more prone to suffer from morbidities than term infants. Hypothermia is the leading cause of morbidity in both term (61\%) and late pre-term (85\%) infants.

\section{KEYWORDS}

Late Preterm Infants, Morbidity, Mortality.

HOW TO CITE THIS ARTICLE: Ajmera S, Surender K, Avinash BS, et al. A clinical study of morbidity and mortality pattern of late preterm infants at SNCU, Warangal. J. Evolution Med. Dent. Sci. 2016;5(19):917-919, DOI: 10.14260/jemds/2016/213

\section{INTRODUCTION}

Late preterm infants, defined by birth at $340 / 7$ through $366 / 7$ weeks' gestation are physiologically and metabolically less mature than term infants. Thus they are at a higher risk of morbidity and mortality than term infants. $(1,2)$ Preterm labor, pre-eclampsia and premature rupture of membranes are known contributors to preterm birth; however, recent spike in inductions, caesarean sections and other obstetrical practices as well as a modest change in maternal demographics have played a key role in the increase in late preterm birth. ${ }^{(3,4)}$ Late preterm infants can present with a multitude of clinical problems including respiratory distress, hyperbilirubinemia, temperature instability, feeding difficulties, hypoglycemia, apnea and late onset sepsis leading to prolonged hospital stay and readmission after discharge.

There is often a false sense of security among birth attendants and families regarding late preterm infants as their size and birth weight appear near normal, hence are less prepared for a medical issue.

Financial or Other, Competing Interest: None.

Submission 01-02-2016, Peer Review 14-02-2016,

Acceptance 16-02-2016, Published 04-03-2016.

Corresponding Author:

Dr. Sudhakar Ajmera,

Assistant Professor, Department of Paediatrics,

MGM Hospital, Kakatiya Medical College,

Warangal, Telangana State, India.

E-mail: drajmerasudhakar@yahoo.co.in

DOI: $10.14260 /$ jemds $/ 2016 / 213$
However, recent data from worldwide including our country suggests that late preterm infants physiologically behave more as preterm and not as term infants.(5)

Understanding morbidity risk among late preterm infants is not only important for helping new-born care providers to anticipate and manage potential morbidity during the birth hospitalization and earlier followup after hospital discharge, but may also possibly assist in guiding nonemergency obstetric intervention decisions.(5) Moreover, majority of previous studies were done in urban areas, hence an attempt was made to recognize proportions of different morbidities and mortality pattern of all late preterm infants who reported on or before $4^{\text {th }}$ day of life and in comparison to equal number of term infants admitted in SNCU (Sick Care Newborn Unit), MGM Hospital, Warangal, Telangana. This is a regional tertiary government hospital in the district catering to population predominantly hailing from surrounding rural areas and low socio-economic group.

\section{METHOD}

This hospital based prospective observational study conducted at SNCU, Mahatma Gandhi Memorial Hospital, Warangal. This study was approved by Hospital Ethical Committee. Consecutive sample of late preterm infants (340/7 to $\left.36^{6 / 7}\right)$ and term infants $\left(370 / 7\right.$ to $\left.41^{6 / 7}\right)$ admitted on or before $4^{\text {th }}$ day of life whose parents had given consent to participate in the study were enrolled. This study was conducted between December 2013 and May 2014. 
Infants with major congenital malformation and clinically identifiable syndromes were excluded. Gestational age was assessed with expanded new Ballard score or based on LMP dating.

The findings of the infants were documented on a regular basis during hospital stay till discharge or death in a predesigned proforma. No follow-up was done after discharge.

\section{DEFINITION OF VARIABLES}

Any of the following pre-defined medical condition resulting in admission during first four days of life - (i) Hypothermia: Axillary temperature less than $36^{\circ} \mathrm{C}$ using low reading clinical thermometer, documented any time during hospital stay, (ii) Hypoglycemia: Random blood sugar was done using glucometer (GRBS) and if the value was less than $45 \mathrm{mg} / \mathrm{dL}$ (As per SNCU guidelines) was considered as hypoglycemia. GRBS was done for all infants on admission and subsequently in accordance with clinical situation. (iii) Apnea: Apnea was defined as cessation of airflow $>20$ sec and/or bradycardia with heart rate $<100$ beats/min or hypoxemia detected clinically by cyanosis or by oxygen saturation monitor along with cessation of airflow. (iv) Sepsis: Probable sepsis was considered when septic screen was positive (two of the five parameters were positive, namely total Leucocyte count $<5000 / \mathrm{mm}^{3}$ or $>15000 / \mathrm{mm}^{3}$, band to total polymorph ratio $>0.2$, absolute neutrophil count less than $1800 / \mathrm{mm}^{3}$, C-reactive protein $>0.5 \mathrm{mg} / \mathrm{dL}$, micro ESR $>15 \mathrm{~mm} / 1^{\text {st }}$ hour). Proven sepsis was defined as isolation of pathogen from blood or urine or CSF. Both probable sepsis and proven sepsis were included under this category. (v) Jaundice: Clinically visible jaundice requiring phototherapy as per hour specific Total Serum Bilirubin (TSB) nomogram (American Academy of Paediatrics bilirubin nomogram.(6) (vi) Respiratory distress: According to SNCU guidelines, respiratory rate $>60 / \mathrm{min}$ and/or having grunt or chest retractions. Respiratory morbidities were defined as per National Neonatal Perinatal Database (NNPD) definitions. (7) (vii) Birth Asphyxia: Based on Apgar data from the referral letter or history of delayed cry (Initiation of cry after one minute of life).

\section{STATISTICAL ANALYSIS}

Statistical analysis was done using Chi-square test Yates correction wherever applicable or student ' $t$ ' test for comparing proportions or means respectively based on type of the variable. Odds ratios with $95 \%$ confidence intervals were calculated for variables.

\section{RESULTS}

76 late preterm and an equal number of term infants were enrolled. The mean gestation of late preterm group and term infants were 36.1 and 38.5 weeks respectively. The mean birth weight were $2228 \mathrm{~g}$ and $3125 \mathrm{~g}$ respectively. Mode of delivery was similar between the groups (Table 1).

\begin{tabular}{|c|c|c|c|}
\hline Variable & $\begin{array}{c}\text { Late Pre } \\
\text { term (n 76) }\end{array}$ & $\begin{array}{l}\text { Term } \\
\text { (n 76) }\end{array}$ & p value \\
\hline $\begin{array}{c}\text { Gestation in weeks } \\
\text { Mean (SD) }\end{array}$ & $36.1(0.89)$ & $38.5(1.5)$ & $<0.001$ \\
\hline $\begin{array}{l}\text { Birth weight in } \\
\text { grams Mean (SD) }\end{array}$ & $2228(620)$ & $3125(450)$ & $<0.001$ \\
\hline $\begin{array}{l}\text { Mode of delivery } \\
\text { LSCS n (\%) }\end{array}$ & $41(54)$ & $35(46)$ & 0.36 \\
\hline Vaginal n (\%) & $30(39)$ & $40(53)$ & 0.08 \\
\hline Outlet forceps n (\%) & $5(6)$ & $1(1)$ & 0.09 \\
\hline
\end{tabular}

On comparing the two groups, late preterm infants were significantly at a higher risk of hypothermia, hypoglycemia, sepsis and respiratory distress. There was no significant difference in mortality between the groups albeit a trend towards higher mortality was observed (Table 2).

\begin{tabular}{|c|c|c|c|c|}
\hline $\begin{array}{c}\text { Variable } \\
\text { Present }\end{array}$ & $\begin{array}{c}\text { Late } \\
\text { Preterm } \\
\mathbf{n = 7 6} \\
\mathbf{n}(\%)\end{array}$ & $\begin{array}{c}\text { Term } \\
\mathbf{n = 7 6} \\
\mathbf{n}(\%)\end{array}$ & $\begin{array}{c}\text { Ocvdds } \\
\text { Ratio (CI) }\end{array}$ & $\begin{array}{c}\text { P- } \\
\text { value }\end{array}$ \\
\hline Hypothermia & $\begin{array}{c}65 \\
(85 \%)\end{array}$ & $\begin{array}{c}47 \\
(61 \%)\end{array}$ & $\begin{array}{c}4.4 \\
(1.9-10.2)\end{array}$ & 0.005 \\
\hline Sepsis & $\begin{array}{c}35 \\
(46 \%)\end{array}$ & $\begin{array}{c}20 \\
(26 \%)\end{array}$ & $\begin{array}{c}2.39 \\
(1.2-4.7)\end{array}$ & 0.01 \\
\hline $\begin{array}{c}\text { Respiratory } \\
\text { morbidity }\end{array}$ & $\begin{array}{c}36 \\
(47 \%)\end{array}$ & $\begin{array}{c}18 \\
(24 \%)\end{array}$ & $\begin{array}{c}2.9 \\
(1.4-5.8)\end{array}$ & 0.02 \\
\hline Jaundice & $\begin{array}{c}41 \\
(54 \%)\end{array}$ & $\begin{array}{c}22 \\
(29 \%)\end{array}$ & $\begin{array}{c}2.87 \\
(1.4-5.6)\end{array}$ & 0.02 \\
\hline Hypoglycemia & $\begin{array}{c}15 \\
(19.7 \%)\end{array}$ & $\begin{array}{c}2 \\
(2.6 \%)\end{array}$ & $\begin{array}{c}9.09 \\
(2.0-41.3)\end{array}$ & 0.004 \\
\hline $\begin{array}{c}\text { Birth } \\
\text { asphyxia }\end{array}$ & $\begin{array}{c}17 \\
(22 \%)\end{array}$ & $\begin{array}{c}40 \\
(52 \%)\end{array}$ & $\begin{array}{c}0.25 \\
(0.12-0.52)\end{array}$ & 0.002 \\
\hline \multicolumn{7}{|c|}{ Mortality } & $\begin{array}{c}21 \\
(27 \%)\end{array}$ & $\begin{array}{c}18 \\
(23 \%)\end{array}$ & $\begin{array}{c}1.2 \\
(0.59-2.5)\end{array}$ & 0.57 \\
\hline \multicolumn{5}{|c|}{ Table 2: Comparison of morbidities and mortality } \\
\hline \multicolumn{7}{|c|}{}
\end{tabular}
patterns of late preterm infants

\section{DISCUSSION}

In this study, late preterm infants were at higher risk of morbidity when compared to term infants. Hypothermia was the leading cause of morbidity in late preterm infants (85\%). Even term infants were also hypothermic. Poor thermal care during transport is foremost reason for such a high incidence of hypothermia. Hypothermia tends to compound other morbidities and is independent risk factor for mortality.

Late preterm were also at a higher risk of other morbidities like hypoglycemia, sepsis and respiratory distress. Similar findings were echoed in a prospective cohort study by Jaiswal, et al. and Young PC, et al.(5,8) where $70 \%$ of late preterm suffered from at least one neonatal morbidity. Compared with term infants, late preterm infants were at 5.5 times higher risk for overall morbidity due to any cause, 7.5 times higher risk for respiratory morbidity, 4.2 times higher risk for ventilation (Non-invasive or invasive), 3.4 times higher risk for jaundice and 4.5 times and 2.2 times higher risk for hypoglycemia and probable sepsis, respectively. Tomashek, et al.(9) found that late preterm infants were 1.5 times more likely to require hospital-related care and 1.8 times more likely to be readmitted than term infants, who were breastfed. In another study.(10) late preterm infants were 7 times more likely to have newborn morbidity than term infants $(22 \%$ vs. $3 \%)$. The newborn morbidity rate doubled in infants for each gestational week earlier than 38 weeks. A retrospective study by Wang, et al.(11) showed $77.8 \%$ near term infants compared with $45.3 \%$ of term infants had at least one clinical problem and nearly all clinical outcomes differed significantly between near terms and full term neonates, viz., temperature instability, hypoglycemia, respiratory distress, jaundice.

No significant difference in mortality in late preterm infants and term infants was observed, albeit a trend towards higher mortality was observed. The relatively high mortality rate may be due to late referral, which is common scenario in government tertiary centers. The higher prevalence of hypothermia could also contribute to higher mortality. Proper thermal care from the point of referral and during transport 
will help infants to remain warm and arrive at the tertiary center in a warm state. This can reduce the morbidity burden as well as significantly reduce mortality.

The limitations of our study include small sample size, absence of followup data, especially to look at the readmission rates in the late preterm group.

Thus infants born late preterm are at a higher risk of morbidities, hypothermia being the dominant morbidity.

\section{What is already known?}

Late preterm infants are physiologically less mature than term infants.

\section{What this study adds?}

In comparison with term, late preterm infants are at higher risk for neonatal morbidities, especially hypothermia, jaundice, sepsis, respiratory problems with no significant difference in mortality pattern.

\section{Contributors}

AS and BB designed the study, BS collected the data and analysed the data. All authors contributed to the manuscript and approved the final manuscript.

\section{REFERENCES}

1. Stark AR. American Academy of Paediatrics, Committee on Fetus and Newborn. Levels of neonatal care (Published correction appears in Paediatrics. 2005;115:11-18). Paediatrics 2004.

2. Raju TN, Higgins RD, Stark AR, et al. Optimizing care and outcome for late-preterm (Near-term) gestations and for late preterm infants: a summary of the workshop sponsored by the National Institutes of Health and Human Development. Paediatrics 2006;118:1207-1214.
3. Martin JA, Hamilton BE, Sutton PD, et al. Births: final data for 2003. Natl Vital Stat 2005.

4. Davidoff MJ, Dias T, Damus $\mathrm{K}$, et al. Changes in the gestational age distribution among US singleton births: impact on rates of late preterm birth, 1992 to 2002. Semin Perinatol 2006;30:8-15.

5. Jaiswal A, Murki S, Gaddam P, et al. Early neonatal morbidities in late preterm infants. Indian paediatrics 2011;48:607-611.

6. American academy of paediatrics, subcommittee on hyperbilirubinemia. Management of hyperbilirubinemia in a newborn infant 35 or more weeks of gestation. Paediatrics 2004;114:297-316.

7. National neonatal perinatal database 2003. Available from http://www.newbornwhocc.org/pdf/HRRCReport_2002-03.pdf. Accessed on 28/01/2016.

8. Young PC, Glasgow TS, Xi Li, et al. Mortality of latepreterm (Near-term) newborns in Utah. Paediatrics 2007;119:659-65.

9. Tomashek KM, Shapiro-Mendoz CK, Weiss J, et al. Early discharge among late preterm and term newborns and risk of neonatal mortality. Semin Perinatol 2006;30:618.

10. Shapiro-Mendoza CK, Tomashek KM, Kotelchuck M, et al. Effect of late-preterm birth and maternal medical conditions on newborn morbidity risk. Paediatrics 2008;121:223-32.

11. Wang ML, Dorer DJ, Fleming MP, et al. Clinical outcomes of near-term infants. Paediatrics 2004;114:372-6. 